\title{
Scavenger Receptor Class B Member 1
}

National Cancer Institute

\section{Source}

National Cancer Institute. Scavenger Receptor Class B Member 1. NCI Thesaurus. Code C102463.

Scavenger receptor class B member 1 (552 aa, $61 \mathrm{kDa}$ ) is encoded by the human SCARB1 gene. This protein is involved in the import of lipoproteins. 